\title{
亜鉛めつき浴中における $\mathrm{TiB}_{2} / \mathrm{SiAION}$ 複合セラミックスの摩擦・摩耗特性
}

\author{
中川師夫 ·酒井淳次 ·大八木智仁 · 大河内敬彦* \\ (株) 日立製作所日立研究所, 319-12 茨城県日立市久慈町 4026 \\ *(株) 日立製作所日立工場, 317 茨城県日立市幸町 3-1-1
}

\author{
Friction and Wear Properties of $\mathrm{TiB}_{2} /$ SiAION Composite Ceramics in a Zinc Plating Bath \\ Mitsuo NAKAGAWA, Junji SAKAI, Tomohito OHYAGI ${ }^{\dagger}$ and Takahiko OHKOUCHI* \\ Hitachi Research Laboratory, Hitachi, Ltd., 4026, Kuji-cho, Hitachi-shi, Ibaraki 319-12 \\ *Hitachi Works, Hitachi, Ltd., 3-1-1, Saiwai-cho, Hitachi-shi, Ibaraki 317
}

\begin{abstract}
Friction and wear properties of $\mathrm{TiB}_{2} / \mathrm{SiAlON}$ composite ceramics slid against SiAlON ceramics were investigated in a zinc plating bath and in air. Friction coefficient of $\mathrm{TiB}_{2} / \mathrm{SiAlON}$ in a zinc plating bath was found to decrease monotonically from 0.5 to 0.1 when $\mathrm{TiB}_{2}$ content was increased from 0 to 80 mass \%, but it did not change in air with increasing $\mathrm{TiB}_{2}$ content and was about 0.5 . No wear was observed for $\mathrm{TiB}_{2} / \mathrm{SiAlON}$ although hard particles (dross) were present in the bath, because $\mathrm{TiB}_{2} / \mathrm{SiAlON}$ were harder than the dross. Improved lubrication afforded by better wetting between $\mathrm{TiB}_{2} / \mathrm{SiAlON}$ and the molten zinc may be the primary cause for the reduction of friction coefficient. [Received July 3, 1996; Accepted November 12, 1996]
[R
\end{abstract}

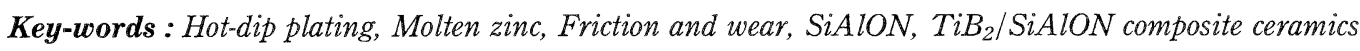

\section{1. 緒言}

鋼板の防食を目的とした被膜形成法として，生産性に優れた 連続溶融亜鉛めっき法が一般に採られている。近年は生産技術 及び品質の向上により，自動車用鋼板等にも用途を広げ，生産 量を伸ばしており, 今後も発展していくものと予想される.

連続溶融亜鉛めっき装置では, 鋼板が連続的に亜鉛めっき浴 を通過する間に鋼板の表面に防食めっきがなされる。一方, めっき装置内で溶融亜鉛と直接接触する浴中部品として広く用 いられている鉄鋼材料は，溶融亜鉛上の反応により激しく溶損 する．特に，シンクロールやサポートロールの軸受け部には滑 り摩擦による機械的応力も加わるので損耗が著しく, 製品の品 質を維持するために短い周期でラインを停止して部品の交換や 補修をしなければならず，生産性や経済性を著しく阻害してい る。したがって，これまでに鉄鋼材料の溶融亜鉛中での耐溶損 性に関して多くの研究や改良がなされてきた1) 3).しかし， 従来の鉄鋼材料ではその限界にきているものと思われる。そこ で更に溶損しがたく摩擦・摩耗特性に優れた新しい材料が望ま れており，上記ロール軸及び軸受けとしてサーメットやセラ ミックスの啇用が試みられている4),5).

著者らは、溶融亜鉛中で種々の材料について溶損及び摩擦・ 摩耗特性を調べ, ロール軸などの摺動部品は, 溶損 (腐食摩耗) と機械的摩耗の相乗効果として激しい摩耗が起こるため耐食, 耐摩耗性に優れたセラミックスが有望な材料であることを明ら かにした ${ }^{6), 7)}$ 。しかし，溶融亜鉛と濡れないセラミックス同士 の滑り摩擦では摩擦係数が大きく実用上問題があっだ た，耐溶損性に優れ，乙かも固体潤滑性を有する炭素系材料を 一方に用いた軸受けでは, 低摩擦係数は得られたが, 浴中に浮 遊する硬質異物が軸受け間に入り込み軟らかい炭素系材料を削 るため, 低摩耗は達成されなかった ${ }^{8)}$ 。現在は, セラミックス に付着する硬質異物を機械的に除去する方法により実機亜鉛 めっき浴中ロール軸受けにセラミックスが使用されている ${ }^{9), 10)}$.

\footnotetext{
$\dagger$ 現在 : 大阪大学医学部, 565 大阪府吹田市山田丘 2-2

Now with Medical Department, Osaka University, 2-2, Yamadaoka, Suita-shi, Osaka 565
}

しかしながら，理想的な摺動部材として，耐溶損性に優れ，し かも溶融亜鉛を潤滑剤として活用することにより低摩擦が得ら れる硬いセラミックスの開発が要望されている。

本研究では, 溶融金属との接触角が小さく, 濡れやすいセラ. ミックスとして知られているが焼結性が悪く，また低強度の木 ウ化チタン $\left(\mathrm{TiB}_{2}\right)^{11)}$ と, 溶融金属との濡れ性は悪いが焼結性 に優れ高強度の焼結体が得られるサイアロン (SiAlON) との 複合セラミックスを作製し, SiAlON を相手材として亜鉛めっ き浴及び大気中で摩擦・摩耗特性を調べた。

\section{2. 実験方法}

\section{1 試料の作製}

試料名と原料の組成を表 1 に，また試料の作製工程を図 1 に 示す.

\section{1 .1 混合・乾燥}

SiAlON 焼結体を得るための原料粉としては, 平均粒径1.5 $\mu \mathrm{m}$ の $\mathrm{Si}_{3} \mathrm{~N}_{4}$ (電気化学工業製, $\mathrm{SN}-9 \mathrm{~S}$ ) t $85 \mathrm{mass} \%$, 平均 粒径 $0.3 \mu \mathrm{m}$ の $\mathrm{Al}_{2} \mathrm{O}_{3}$ （高純度化学研究所製）を $5 \mathrm{mass} \%$, 平 均粒径3 $\mu \mathrm{m}$ の $21 \mathrm{R}$ ポリタイプ $\mathrm{AlN}$ (Lucas 製) を $3 \mathrm{mass} \%$, 平均粒径 $1 \mu \mathrm{m}$ の $\mathrm{Y}_{2} \mathrm{O}_{3}$ （高純度化学研究所製）を7 mass \%を 用いた。 また, $\mathrm{TiB}_{2}$ として, 平均粒径 $7 \mu \mathrm{m}$ の $\mathrm{TiB}_{2}$ (Starck 製）粉末を用いた。表 1 の原料組成となるように SiAlON 原 料粉 $100 \mathrm{~g}$ に対して所定量の $\mathrm{TiB}_{2}$ 粉末を混合し, これにアセ トン $150 \mathrm{ml}$ を加えて, $500 \mathrm{ml}$ のボールミルで約 $24 \mathrm{~h}$ 混合して

Table 1. Sample Names and Nominal Compositions of Powder Mixtures

\begin{tabular}{lcc}
\hline \multirow{2}{*}{$\begin{array}{l}\text { Sample } \\
\text { name }\end{array}$} & \multicolumn{2}{c}{ Component(mass\%) } \\
\cline { 2 - 3 } SiAlON & TiB2 \\
\hline SiAlON & 100 & 0 \\
TB10 & 90 & 10 \\
TB20 & 80 & 20 \\
TB40 & 60 & 40 \\
TB60 & 40 & 60 \\
TB80 & 20 & 80 \\
\hline SiAION : $85 \mathrm{Si}_{3} \mathrm{~N}_{4} \cdot 5 \mathrm{Al}_{2} \mathrm{O}_{3} \cdot 3 \mathrm{AIN} \cdot 7 \mathrm{Y}_{2} \mathrm{O}_{3}$
\end{tabular}




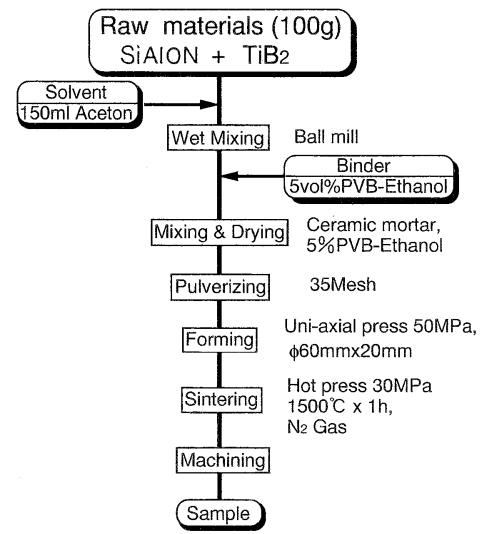

Fig. 1

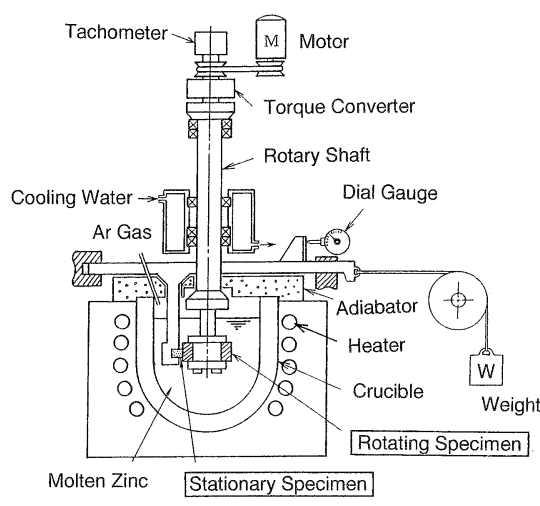

Fig. 2

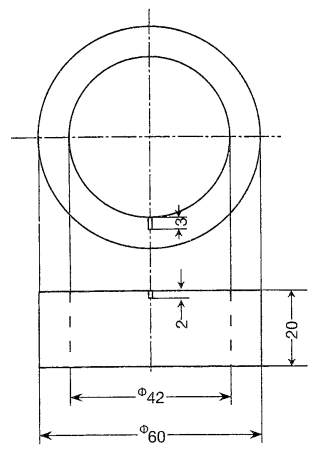

(a)Rotating Specimen

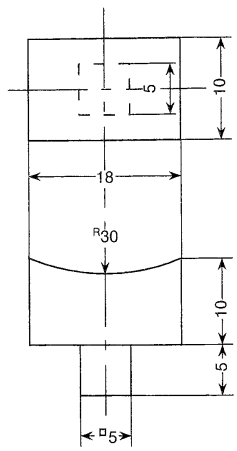

(b) Stationary Specimen

Fig. 3

Fig. 1. Manufacturing process of samples.

Fig. 2. Schematic drawing of friction and wear testing machine.

Fig. 3. Geometry and dimension of specimens.

スラリーを得た．更に，スラリーをらいかい機により混合乾燥 し, 乾燥が終了した後に $5 \mathrm{vol} \%$ のポリビニールブチラール (PVB) を溶解したエタノールを加え, 約 $30 \mathrm{~min}$ 混合・乾燥 した。これを $35 \times ッ シ ュ ~(420 \mu \mathrm{m})$ のふるいにより分級して 成形用粉末を得た。

\section{1 .2 成形・焼結}

成形用粉末を直径 $60 \mathrm{~mm}$ の金型に入れて $50 \mathrm{MPa}$ の圧力を 加え, 直径 $60 \mathrm{~mm} \times$ 厚さ $20 \mathrm{~mm}$ の成形体を得た. 次に, 成形 体をホットプレスにより, 約 $15^{\circ} \mathrm{C} / \mathrm{min}$ の速度で $1500^{\circ} \mathrm{C}$ 加熱 し $\mathrm{h}$ 保持した後, 約 $20^{\circ} \mathrm{C} / \mathrm{min}$ の速度で降温して $\mathrm{TiB}_{2} / \mathrm{SiAl}$ $\mathrm{ON}$ 複合焼結体を得た。雲囲気は昇温時に $1000^{\circ} \mathrm{C}$ まば $80 \mathrm{~Pa}$ に減圧し, 次いで冷却終了まで $500 \mathrm{kPa}$ の窒素ガスとした。 た, 王力は昇温時 $1000^{\circ} \mathrm{C}$ を゙常圧, 次いで $30 \mathrm{MPa}$ の荷重を かけ, 冷却時に $1000^{\circ} \mathrm{C}$ に達した時点で圧力を解除した。 ただ し， $\mathrm{TiB}_{2}$ を含まない SiAlON は常王焼結した。

\section{2 試料の組織及び機械的特性試験}

\subsection{1 組織及び組成分析}

各試料の表面を $1 \mu \mathrm{m}$ ダイヤモンドペーストを用いて鏡面に 研磨し, 光学顕微鏡により組織観察を行った. 更に, 試料 TB20について SEM 及びEDXにより組成分析を行った。

\subsubsection{X線回折}

試料 TB20及びTB40についてX線回折を行い, $\mathrm{TiB}_{2} /$ SiAlON 複合焼結体の結晶を分析した。

\section{2 .3 密度}

各試料について, 曲げ強度試験前の試験片の寸法をマイクロ メーターで, また重量を電子天秤で測定し，これらの值から焼 結体のかさ密度を算出した. 更に, 焼結体が $\beta$-SiAlON と $\mathrm{TiB}_{2}$ のみからなると仮定した理論密度と焼結体のかさ密度と から相対密度を算出した。

\section{2 .4 曲け強度}

各試料の 4 点曲げ強度を, JIS R1601の「ファインセラミッ クスの曲げ強さ試験方法」に従い, クロスヘッドスピードを $0.5 \mathrm{~mm} / \mathrm{min}$ とし, 各組成につき 5 本の試験片を用いて測定し た.

\section{2 .5 ビッカース硬さ}

各試料のビッカース硬さを荷重 $100 \mathrm{~N}$, 負荷時間 $15 \mathrm{~s}$ の条件 で測定した。

\section{3 摩擦・摩耗試験}

\subsection{1 試験装置}

本研究に用いた試験装置の概要を図 2 に示す。本装置では,
縦型加熱炉内の溶融金属中に円筒状の回転試験片と, その側面 に接触する固定試験片を浸漬し, 加圧接触させて種々の液体中

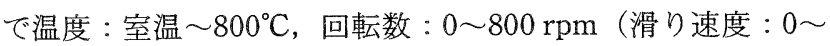
$150.8 \mathrm{~m} / \mathrm{min}$, ただし回転側試験片の半径: $30 \mathrm{~mm}$ ), 荷重 : $0 \sim 0.5 \mathrm{kN}$ (面圧 : $0 \sim 2.8 \mathrm{MPa}$ ，ただし固定側試験片の接触面 積 : $180 \mathrm{~mm}^{2}$ ) の条件で滑り摩擦・摩耗特性を評価することが できる。

\subsection{2 試験方法}

試験片の形状及び寸法を図 3 に示す。回転側試験片としては 常圧焼結法で作製した SiA1ON 焼結体を用い，固定側試験片 には図 1 の工程で作製した $\mathrm{TiB}_{2} / \mathrm{SiAlON}$ 複合焼結体を用い た。摩擦・摩耗試験条件を表 2 に示す。面圧を 2 段階, 滑り 速度を 3 段階に変化させた。 また, 雲囲気は室温大気中と $480^{\circ} \mathrm{C}$ 亜鉛浴中の 2 種類とし, 亜鉛浴で試験する際には, 浴 面にアルゴンガスを吹き付け溶融亜鉛の酸化を防止した．亜鉛 浴としては実機連続亜鉛めっき装置で使用されているものに近 い組成で $\mathrm{Al}-\mathrm{Fe} や \mathrm{Zn}-\mathrm{Fe}$ 化合物を含んだ0.15 Al-0.1 Pb-Zn (mass\%) を用いた。試験時間はおのおのの面圧及び試験条件 のもとで大気中では 5 10 $\mathrm{min}$, 垔鉛浴中では30 $\mathrm{min}$ 以上と した。大気中では摩擦係数が大きいため試験時間は短くし，ま た高面圧，高速での試験は行わなかった，一方，亜鉛浴中で は, 各条件での初期摩耗が終わり摩擦係数が安定するまで試験 を続行した。しかしながら，亚鉛浴中に打いても摩擦係数が大 きく，また摩耗が激しい時は試験時間を短くした。

\section{1 試料の組織及び機械的特性}

\section{3. 実験結果及び考察}

\section{1 .1 組織及び組成}

SiAlON 及び $\mathrm{TiB}_{2} / \mathrm{SiAlON}$ の光学顕微鏡写真を図 4 に示す. 図 4 (a) はSiAlON で 2 3 $\mu \mathrm{m}$ の気孔が見られる.図 4 (b)〜 (f) は $\mathrm{TiB}_{2} / \mathrm{SiAlON}$ で $\mathrm{SiAlON}$ 中に粒径 $5 \sim 10 \mu \mathrm{m}$ の $\mathrm{TiB}_{2}$ 粒 子（写真で白い部分）が分散して抢り， $\mathrm{TiB}_{2}$ を多く含むむの ほど, 分散量は多くなっている。気孔（写真で黒い部分）は

Table 2. Experimental Conditions of Friction and Wear Tests

\begin{tabular}{|l|c|c|}
\hline \multicolumn{1}{|c|}{ Atmosphere } & Air & Molten Zinc \\
\hline \multicolumn{1}{|c|}{ Temperature } & R.T. & $480^{\circ} \mathrm{C}$ \\
\hline Contact pressure (MPa) & $0.36,(0.97)$ & $0.36,0.97$ \\
\hline Sliding speed (m/min) & $15,25,40$ & $15,25,40$ \\
\hline Testing time $(\mathrm{min})$ & $5 \sim 10$ & 30 \\
\hline
\end{tabular}

${ }^{*}$ Composition of molten zinc : $0.15 \mathrm{Al}-0.1 \mathrm{~Pb}-\mathrm{Zn}$ (mass $\%$ ) 


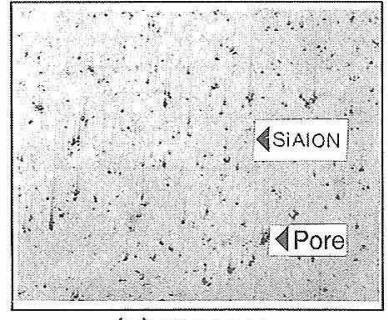

(a) SIAION

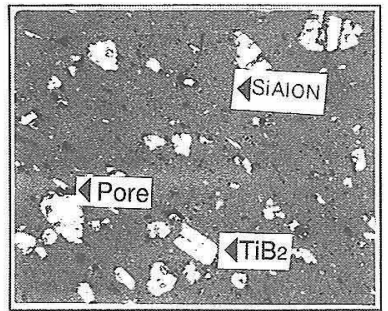

(b) TB10

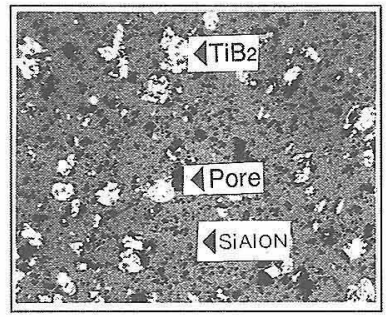

(c) TB20

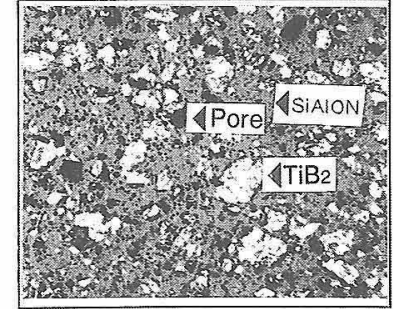

(d) TB40

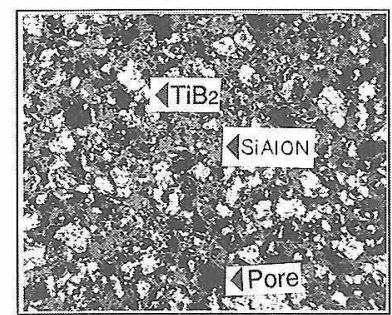

(e) TB60

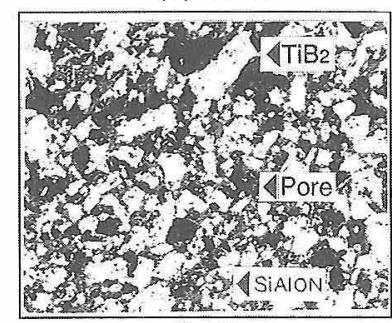

(i) TB80
$20 \mu \mathrm{m}$

Fig. 4. Optical micrographs of $\mathrm{SiAlON}$ and $\mathrm{TiB}_{2} / \mathrm{SiAlON}$ composite ceramics.

$\mathrm{TiB}_{2}$ と $\mathrm{SiAlON}$ との界面に多く存在し， $\mathrm{TiB}_{2}$ の割合が多いほ ビ多くなっていることが観察される。相対密度に比べ, 写真に おいて気孔が多く観察されるのは, 断面の切削, 研磨で表面の $\mathrm{TiB}_{2}$ 粒子の一部がはく離・脱落したためと考えられる.

図 5 KTB20のSEM写真々それに対応したTi の面分析結 果を示す。これより分散している粒子は $\mathrm{Ti}$ を含む成分，すな わち $\mathrm{TiB}_{2}$ であり, 得られた烍結体は, $\beta$ - $\mathrm{SiAlON}$ 中に $\mathrm{TiB}_{2}$ が 分散し, また $\mathrm{TiB}_{2}$ の近傍には気孔が集中した構造の複合焼結 体である。

\section{$3.1 .2 \times$ 線回新}

TB20及びTB40のX線回折結果を図 6 に示す、X 線回折図 は，いずれる $\beta$-SiAION と TiB 2 による回折ピークの重なりか らなる。したがって焼結体は， $\beta$-SiAION と $\mathrm{TiB}_{2}$ との混合物 からなることが分かる。

\section{1 .3 密 度}

各試料の密度の測定結果を表 3 に示す。これより $\mathrm{TiB}_{2}$ を多 く含むほぼ相対密度が下がる傾向には岁るが， $\mathrm{TiB}_{2}$ を80 mass\%複合しても相刘密度 $90 \%$ と高い焼結密度が得られた。

また, $\mathrm{TiB}_{2}$ と SiAION との界面は, $\mathrm{TiB}_{2}$ の割合が多いほど多 くなり, $\mathrm{TiB}_{2} / \mathrm{SiAlON}$ の気孔は主に焼結性の悪い $\mathrm{TiB}_{2}$ と $\mathrm{SiAl}$ ON との界面に生ずるので，それに伴って気孔の量も増加す る. $\mathrm{TiB}_{2}$ 複合率 20 mass\%で密度が低下しているが，その理 由としては，焼結温度が他のものに比べてやや高く, $\mathrm{TiB}_{2}$ の 酸化または窒化反応 ${ }^{12)} か ゙$ 進んだためと考えられる。

\section{1 .4 曲げ強度}

SiAlON 及び $\mathrm{TiB}_{2} / \mathrm{SiAlON}$ の 4 点曲げ強度試験結果を図 7 に示す. SiAION に10 mass\%でむ $\mathrm{TiB}_{2}$ を複合させると, 強度 が SiA1ON の約半分の約 $430 \mathrm{MPa}$ 女で低下するが，10 mass\% から60 mass\%まで增加した試料の強度は $400 \mathrm{MPa}$ から500

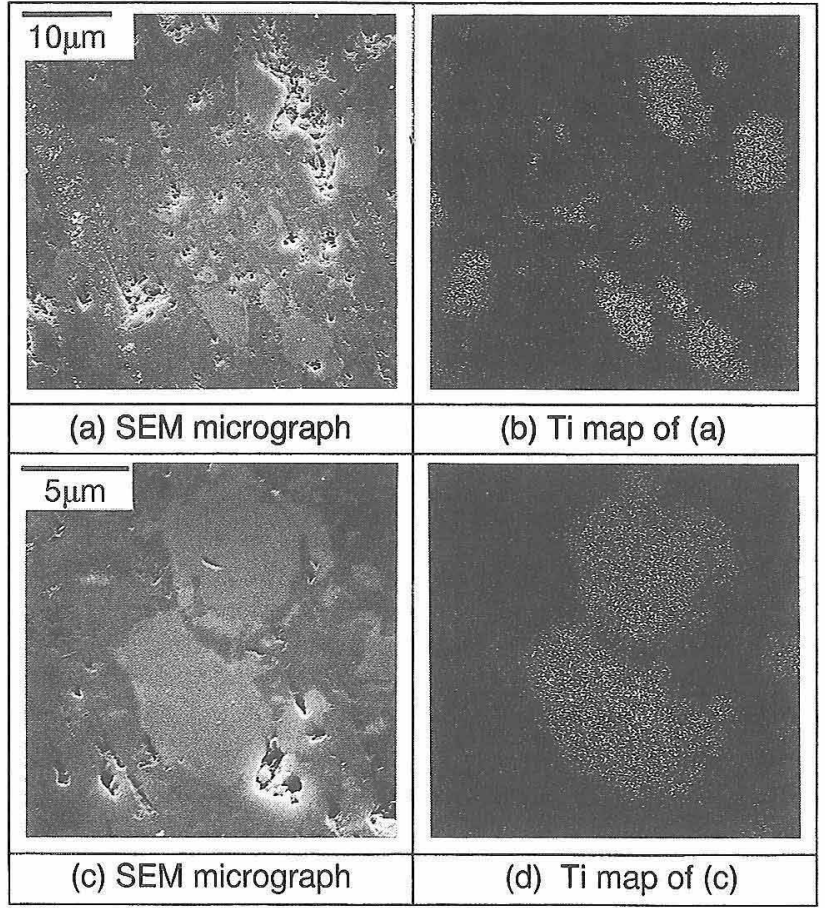

Fig. 5. SEM micrographs and Ti mapping of the surface in sample TB20.

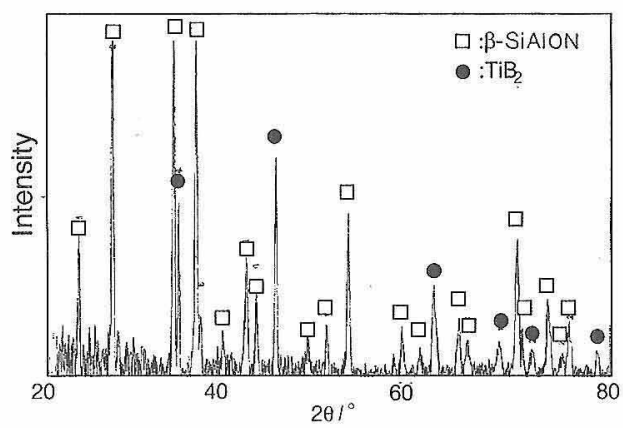

(a) TB20

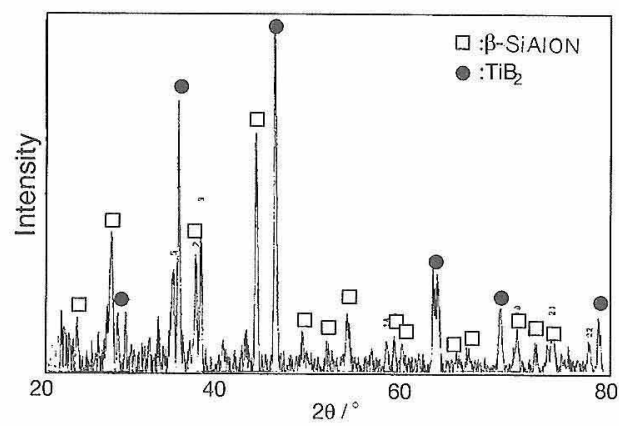

(b) TB40

Fig. 6. X-ray diffraction profile of samples TB20 and TB40.

Table 3. Density of SiAlON and $\mathrm{TiB}_{2} / \mathrm{SiAlON}$ Composite Ceramics

\begin{tabular}{|l|c|c|c|}
\hline $\begin{array}{l}\text { Sample } \\
\text { name }\end{array}$ & $\begin{array}{c}\text { Bulk } \\
\text { density } \\
\left(\mathrm{Mg} / \mathrm{m}^{3}\right)\end{array}$ & $\begin{array}{c}\text { Ideal } \\
\text { density } \\
\left(\mathrm{Mg} / \mathrm{m}^{3}\right)\end{array}$ & $\begin{array}{c}\text { Relative } \\
\text { density } \\
(\%)\end{array}$ \\
\hline SiAlON & 3.31 & 3.31 & 100 \\
\hline TB10 & 3.40 & 3.38 & 99 \\
\hline TB20 & 3.30 & 3.50 & 94 \\
\hline TB40 & 3.62 & 3.71 & 97 \\
\hline TB60 & 3.73 & 3.94 & 94 \\
\hline TB80 & 3.80 & 4.21 & 90 \\
\hline
\end{tabular}




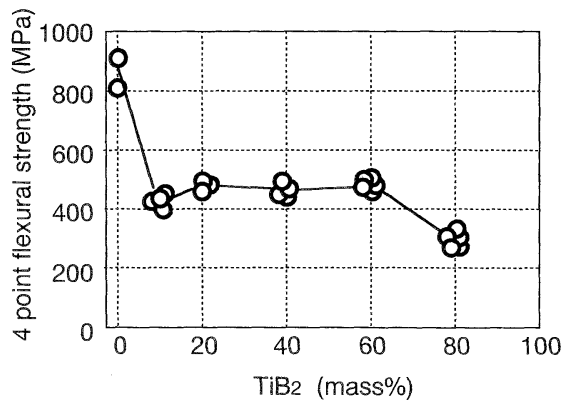

Fig. 7. Flextual strength of $\mathrm{SiAlON}$ and $\mathrm{TiB}_{2} / \mathrm{SiAlON}$ composite ceramics.

$\mathrm{MPa}$ 程度の值で変化は少ない。しかし， 80 mass\%まで増加 すると，強度は再び低下し， $300 \mathrm{MPa}$ 程度となった。

$\mathrm{TiB}_{2} / \mathrm{SiAlON}$ は物理・機械的性質の異なる材料を組み合わ せて生成した材料であるので, 強度は単一材料之異なり, マト リックスや複合材の性質ばかりでなく異種材料を結合した界面 の影響も受ける. 更に, セラミックスの強度は, 気孔の大きさ や気孔率に支配されることも良く知られている13),14). 曲げ試 験の結果から 10 mass\%の $\mathrm{TiB}_{2}$ の添加による強度の低下は $\mathrm{TiB}_{2}$ の強度が低い11),15)ことに起因しているものと思われる. また, 強度の変化を表 3 の相対密度や図 4 の光学顕微鏡写真 から $\mathrm{TiB}_{2} / \mathrm{SiAlON}$ 中の気孔率と関係づけて考察することがで きる。すなわち， $\mathrm{TiB}_{2}$ の複合率が 10 mass\%から 60 mass\%の 範囲では，いずれも気孔は $\mathrm{TiB}_{2}$ 粒子レベルの大きさで気孔率 の変化も少なく, マトリックスである $\mathrm{SiAlON}$ 同士の結合が なされているので, この範囲の $\mathrm{TiB}_{2}$ 複合率では, $\mathrm{TiB}_{2}$ の量 にかかわらず強度がほぼ一定になったと考えられる．更に， $\mathrm{TiB}_{2}$ 複合率が 80 mass\%に增加すると, 図 4 (f)からマトリッ クスであるSiAlON 同士の結合が途切れ, 気孔の連結が観察 され，相対密度も低下している。したがって, $\mathrm{TiB}_{2}$ 複合率を 80 mass\% と増した際に強度が再び低下したものと考えられ る。

\section{1 .5 ビッカース硬さ}

$\mathrm{TiB}_{2} / \mathrm{SiAlON}$ のビッカー久硬さ測定の結果から, $\mathrm{TiB}_{2}$ 複合 率とビッカース硬さの関係を図 8 に示す。 $\mathrm{TiB}_{2}$ 複合率が 60 mass $\%$ 程度までは, $\mathrm{TiB}_{2}$ 複合率の増加に伴って硬さが 15 $\mathrm{GPa}$ から $20 \mathrm{GPa}$ に増している。この範囲の $\mathrm{TiB}_{2}$ 複合率で硬 さを支配するのは，焼結体を構成する成分の硬さと考えられ る. $\mathrm{TiB}_{2}$ のマイクロビッカース硬さは約 $30 \mathrm{GPa}^{11)}$, また $\mathrm{SiAl}$ ON のビッカース硬さは約 $15 \mathrm{GPa}$ であるので, $\mathrm{TiB}_{2}$ 複合率が 多いものほど, 硬さが高くなったと考えられる. 更に, $\mathrm{TiB}_{2}$ 複合率が 80 mass \% になると, 相対密度が低下し, 気孔の存在 がマクロ的な硬さに及ぼす影響が強くなるために, 硬さが下 がったと考えられる。しかしながら，いずれの $\mathrm{TiB}_{2} / \mathrm{SiAlON}$ に打いてもドロス (Al-Fe系で約 $7 \mathrm{GPa}, \mathrm{Zn}-\mathrm{Fe}$ 系で約 $4 \mathrm{GPa})^{9)}$ よりも硬さが高く, ドロスによって摩耗されにくいこ とが予想される。

\section{2 摩擦・摩耗特性}

\section{2 .1 摩擦係数}

回転側試験片をSiAION, 固定側試験片をSiAlON 及び $\mathrm{TiB}_{2} / \mathrm{SiAlON}$ として大気中及び覀鉛めっき浴中で滑り摩擦さ せた場合の摩擦係数の測定例を SiAlON 及びTB40について 図 9 に示す. SiAlON 同士の摩擦では, 大気中, 亜鉛めっき浴 中のいずれに扔いても, 摩擦係数は 0.5 付近の高い值を示し, 摩擦時に高いさしみ音が発生した。これは, SiAlON が溶融亜 鉛に濡れず，亜鉛めっき浴中においてもSiAlON 同士が大気

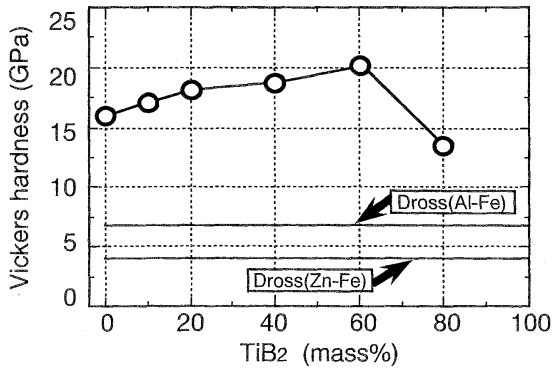

Fig. 8. Hardness of SiAlON and $\mathrm{TiB}_{2} / \mathrm{SiAlON}$ composite ceramics.

(a) SiAION

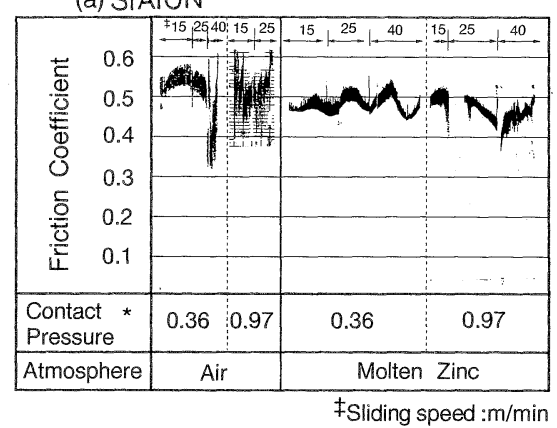

(b) TB40

*Unit: $\mathrm{MPa}$

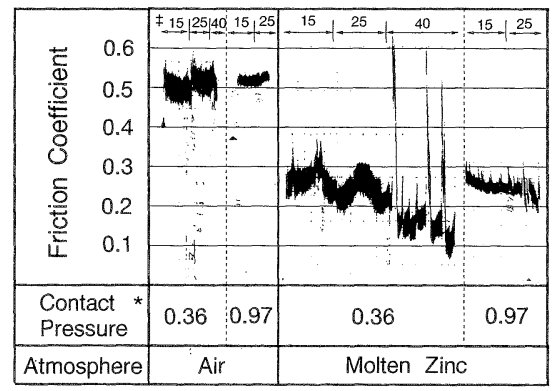

Fig. 9. Dependency of contact pressure and sliding speed on friction coefficient between (a) SiAION and SiAlON, (b) SiA1ON and TB40.

中と同様に乾式接触し, 高い摩擦抵抗を示すためと考えられ る。これに対し $\mathrm{TiB}_{2} / \mathrm{SiAlON}$ と SiAlON との摩擦に打いて は，大気中では 0.5 付近の高い摩擦係数を示すものの，亜鉛 めっき浴中では大気中に比べ摩擦係数は低下した。また，この 組み合わせの摩擦でも大気中では SiAlON 同士の摩擦之同様, 高いきしみ音が発生するのに対し，亜鉛めっき浴中ではきしみ 音は消え, 溶融亜鉛が潤滑剂として働いたことが示唆された.

亜鉛めっき浴中での摩擦試験で，面圧を $0.36 \mathrm{MPa}$ で一定之 し, 滑り速度を $15,25,40 \mathrm{~m} / \mathrm{min}$ と変化させた場合の $\mathrm{TiB}_{2} /$ $\mathrm{SiAlON}$ 複合焼結体中の $\mathrm{TiB}_{2}$ 複合率々摩擦係数々の関係を 図10に示す。ただし，ドロスなどのかみ込みにより一時的に摩 擦係数の上昇があったが，その值は除いて整理した。これよ り, $\mathrm{TiB}_{2}$ 複合率の増加に伴い, 亜鉛めっき浴中での摩擦係数 は低下し, 滑り速度が速いほど小さくなっている。特に, $\mathrm{TiB}_{2}$ を8 80 mass\%あで複合させることにより，亜鉛めっき浴中 での摩擦係数は0.1前後の值となり, SiAlON と固体潤滑性を 有する炭素材との組み合わせ6) と，ほぼ同じレベルに達した。

以上の結果より, $\mathrm{TiB}_{2}$ による摩擦係数の低下は $\mathrm{TiB}_{2}$ の 割合が増加するほど顕著となり, 液体が摩擦面に介在したとき に特改的な摩擦係数の速度依存性が見られた。したがって, SiAlON は亜鉛めっき浴中でも大気中と同様に摩擦係数が大き 


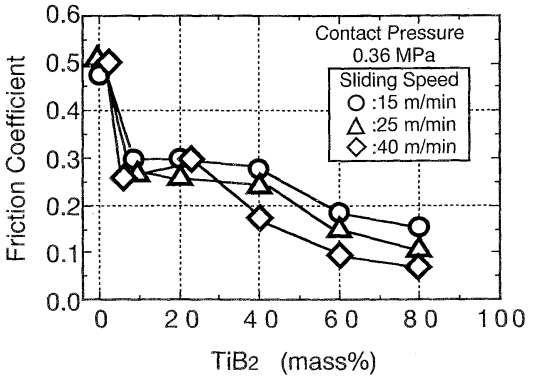

Fig. 10. Effect of $\mathrm{TiB}_{2}$ content on friction coefficient between SiAlON and $\mathrm{TiB}_{2} / \mathrm{SiAlON}$ composite ceramics in a zinc plating bath.

いのに対して, $\mathrm{TiB}_{2} / \mathrm{SiAlON}$ が亜鉛めっき浴中で摩擦係数が 低下する理由として, $\mathrm{TiB}_{2}$ を複合させることにより, $\mathrm{SiAlON}$ の溶融亜鉛に対する濡れが良くなり，溶融金属が潤滑剂として 働くためと考えられる.

しかし, $\mathrm{TiB}_{2} / \mathrm{SiAlON}$ の亜鉛めっき浴中での摩擦係数は, 得られた最も低い值でも0.05程度であった．摺動部材間に摺動 部の表面粗さより厚い境界膜が生成する流体潤滑によって潤滑

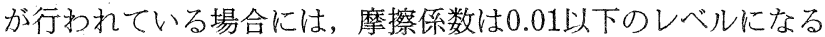
ことが一般的であるので，ここで得られた結果は潤滑剤が関与 する潤滑のモードとしてはストライベック曲線で示される境界 潤滑と流体潤滑の間に存在する混合潤滑領域16) とみなされ， 高速度ほど溶融业鉛の摩擦面への流入が多く, 流体潤滑効果が 大きくなり，摩擦係数が低下したものと考えられる。

\section{2 .2 摩耗特性}

大気中及び亜鉛めっき浴中で SiAlON と SiAlON を組み合 わせた場合には摩擦係数が大きく，なた高いきしみ音が発生し たため，摩耗量の測定は行わなかった。

亜鉛めっき浴中で $\mathrm{TiB}_{2} / \mathrm{SiAlON}$ と SiAlON との組み合わせ での摩擦試験を行った場合の摩耗量は $\mathrm{TiB}_{2}$ 複合率にかか水ら ず，約 $6 \mathrm{~h}$, 約 50,000回転（約 $9.5 \mathrm{~km}$ ）の摩擦試験後において も0.1 mm 以下であり，これまでに SiAlON と種々の材料の組 久合わせで得られた摩耗量7に比較して微小であった。図11に 要鉛めっき浴中で測定したTB80に抢けるドロ久等の巻き込み と摩耗挙動を摩擦係数と合わせて示す. 円滑に潤滑されている ときばかりでなく，ドロス等を巻き込んで一時的に摩擦係数が 増大しても摩耗はほとんど進行していないことが分かる。すな わち，ドロス等の巻き込みにより摩擦係数が一時的に増大した 際に摩耗(変位)は負の值を示すが再び元の值に復帰している. これは大きなドロス等が摩擦面に巻き込まれても，それが除去 されると変位は元に戻り，摩耗でないことを示すものである。

$\mathrm{TiB}_{2}$ 複合率にかかわららず， $\mathrm{TiB}_{2} / \mathrm{SiAlON}$ の摩擦試験では，図 11 と同様に，ドロス等を巻き込んでも，それによって摩耗は 進行しなかった。すなわち，円滑に摩擦しているときにはセラ ミックス間に潤滑膜が形成されており，またドロス等を巻き込 んでも $\mathrm{TiB}_{2} / \mathrm{SiAlON}$ はドロスの 2 倍以上の硬さを有するため 摩耗が生じにくいものと思われる。

\section{4. 結 論}

溶融亜鉛に対する SiAION セラミックスの濡れ性の向上を 図り，亜鉛めっき浴中で滑り摩擦した際に，溶融亜鉛を潤滑剂 として活用できる低摩擦・摩耗摺動材の開発を目的として $\mathrm{TiB}_{2} / \mathrm{SiAlON}$ 複合焼結体を作製し，その機械的特性及び SiAlON と組み合わせた場合の摩擦・摩耗特性を大気中々亜鉛 めっき浴中で評価し, 以下の結果を得た。

\begin{tabular}{|c|c|c|}
\hline $\begin{array}{l}\text { Wear } \\
\text { Amount }\end{array}$ & & $0.1 \mathrm{~mm}$ \\
\hline \multirow{6}{*}{ 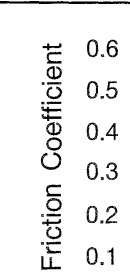 } & \multicolumn{2}{|l|}{ Sliding Speed: $40 \mathrm{~m} / \mathrm{min}$} \\
\hline & $5 \mathrm{~min}$ & \\
\hline & & \\
\hline & & \\
\hline & : & \\
\hline & : & \\
\hline $\begin{array}{l}\text { Contact } \\
\text { Pressure }\end{array}$ & $0.36 \mathrm{MPa}$ & \\
\hline Atmosphere & Molten Zinc & \\
\hline
\end{tabular}

Fig. 11. Change in wear amount and friction coefficient of TB80 sliding against SiA1ON when dross is between the sliding faces in a zinc plating bath.

（1）ホットプレス法により複合率の異なる $\mathrm{TiB}_{2} / \mathrm{SiAlON}$ 複合焼結体が得られた。気孔は $\mathrm{TiB}_{2}$ 粒子の近傍に存在し， $\mathrm{TiB}_{2}$ の割合が増すにつれて上昇した。

(2) $\mathrm{TiB}_{2}$ の割合が増すにつれて相対密度，強度ともに低下 し, 40 mass $\% \mathrm{TiB}_{2} / \mathrm{SiAlON}$ では相対密度が約 $95 \%$ ，強度が SiAlONの約 1/2 に下がり, 80 mass $\% \mathrm{TiB}_{2} / \mathrm{SiAlON}$ では相 対密度が約 $90 \%$ 、強度が約 $1 / 3$ に低下した。

（3） SiAlON 同士の摺動では，大気中，亜鉛めっき浴中共 に約 0.5 と高い摩擦係数を示したのに対し， $\mathrm{TiB}_{2} / \mathrm{SiAlON}$ は, 大気中では SiAlON 同士の組み合わせと同様に高い摩擦係数 を示したが，亜鉛めっき浴中では $\mathrm{TiB}_{2}$ の割合が増すにつれて 低下し， 80 mass \% TiB $/$ SiAlON では約 0.1 まで低下した。

(4) $\mathrm{TiB}_{2} / \mathrm{SiAlON}$ は, ドロスなどの硬質粒子を含む亜鉛 めっき浴中に扔いても摩耗は微小であった。

\section{文 献}

1) E. J. Daniels, J. Metals, XLVI, 81 (1931)

2）中村 勇，山根壽巳，越久村信次，日立造船技法，21，212$16(1960)$.

3）宇部善満，森原豊多，山崎大蔵，中川義清，岸川利一，山口 登男，三菱重工技法，7，83-88 (1970)。

4）中平宏, 原田良夫, 谷 和美, 小林圭史, 日本金属学会会 報，31，446-48（1990）。

5）可児保宣，飯田芳彦，中川師夫，大河内敬彦，木村光男，日 立評論, 72, 429-36 (1990)。

6）中川師夫，酒井淳次，大河内敬彦，大越 斉，鉄と鋼， 81 , 989-94 (1995).

7）中川師夫，酒井淳次，大河内敬彦，大越 斉，鉄々鋼， 82, 226-31 (1996)

8）中川師夫, 荻原 覚, 酒井淳次, 大河内敬彦, 大越 斉, 材 料とプロセス, 8, 1560 (1995).

9）大河内敬彦，川東民人，中川師夫，酒井淳次，大越 斉，材 料とプロセス, 7, 1536 (1994).

10）中川師夫, 酒井淳次, 大河内敬彦, 大越 斉, 鉄と鋼, 82, 689-94 (1996)

11）ゲ・ヴェ・サムソノフ，イ・エム・ヴィニッキー，“データ ブック高融点化合物便覧”，日ソ通信社 (1977) pp. 287-91, pp. 399-409.

12）エル・エフ・ボイトヴィチ，“難融性化合物便覧一熱力学的 特性一”，日ソ通信社 (1971) pp. 12-20.

13) E. Ryshkewitch, J. Am. Ceram. Soc., 36, 65-68 (1953).

14） W. D. Kingery, H. K. Bowen and D. R. Uhlmann, (小松和蔵 ら共訳)，“セラミックス材料科学入門 (応用編)”，内田老鶴 戋新社 (1981) pp. 779-82.

15）“'94年度版ファインセラミックスデータブック”，工業材料, 日刊工業新聞 $(1994)$ p. 117 .

16）木村好次, “トライボロジーデータブック”，テクノシステム (1991) pp. 18-24. 